\title{
КҮРІШ САБАНЫ МЕН МҰНАЙ ШЛАМЫН ҚОСЫП ӨНДЕУ АРҚЫЛЫ ТҮЙІРШІКТЕЛГЕН КӨМІР АДСОРБЕНТІН АЛУ
}

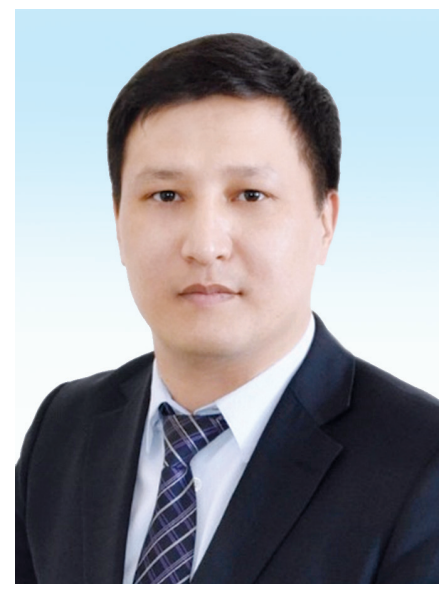

H.O. АППАЗОВ ${ }^{1,2}$,

химия ғылымдарының кандидаты, профессор, Ыбырай Жақаев атындағы Қазақ күріш шаруашылығы ғылыми-зерттеу институты

Басқарма Төрағасының м.а., https://orcid.org/0000-0001-8765-3386

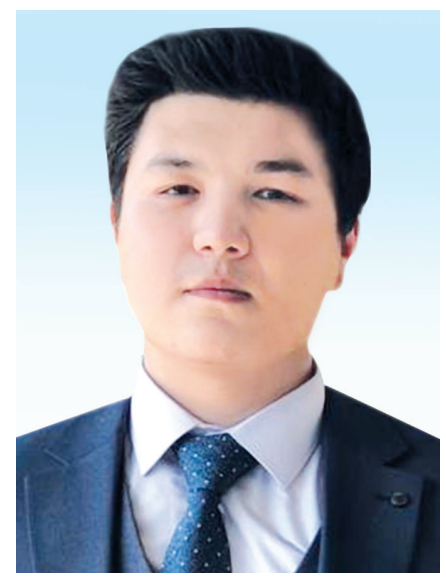

Б.М. БАЗАРБАЕВ ${ }^{1}$, «Физика-химиялық талдау әдістері» инженерлік бейіндегі зертхана инженері, http://orcid.org/0000-0003-1574-8145

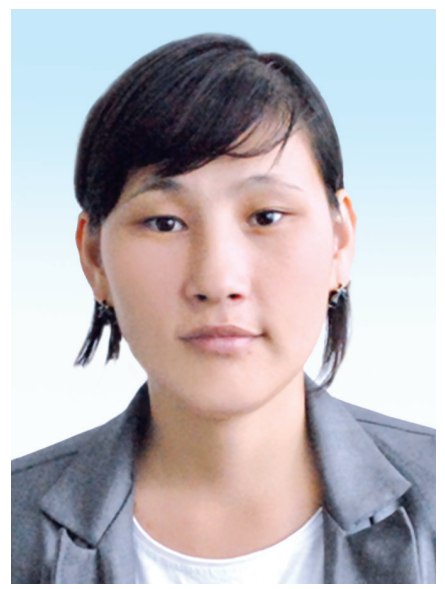

Б.М. ДИЯРОВА «Химия» мамандығы бойынша $\mathrm{PhD}$ - докторант, https://orcid.org/0000-0002-1086$369 X$

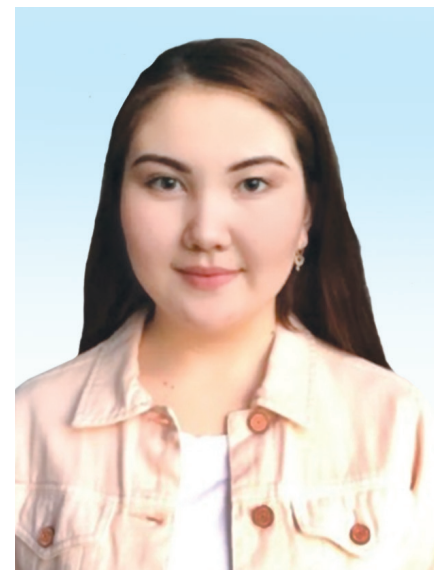

Т. АСЫЛБЕККЫЗЫ ${ }^{1}$ «Бейорганикалық заттардың химиялық технологиясы» мамандығының магистранты, https://orcid.org/0000-0001-5337-2164

С.А. КАНЖАР ${ }^{1}$, «Органикалық заттардың химиялық технологиясы» мамандығының студенті, https://orcid.org/0000-0003-4553-3049 
${ }^{1}$ ҚОРҚЫТ АТА АТЫНДАҒЫ ҚЫЗЫЛОРДА МЕМЛЕКЕТТІК УНИВЕРСИТЕТІ,

Қазақстан Республикасы, 120014, Қызылорда қ., Әйтеке би көшесі, 29A

ЫБЫРАЙ ЖАҚАЕВ АТЫНДАҒЫ ҚАЗАҚ КҮРІШ ҒЫЛЫМИ-ЗЕРТТЕУ ИНСТИТУТЫ, Қазақстан Республикасы, 120014, Қызылорда қ., Абай даңғылы 25Б

ЗЗАЗАҚ ҰЛТТЫҚ ҚЫЗДАР ПЕДАГОГИКАЛЫҚ УНИВЕРСИТЕТІ, Қазақстан Республикасы, 050000, Алматы қ., Айтеке би көшесі, 99

Бұл мақалада белсендірілген көмір алу үшін күріш қалдығымен мұнай қалдығына байланыстырушы карбоксиметилцеллюлозаның әсері зерттелді. Күріш қалдығы (қауызы және сабаны) мен мұнай шламын бірге өңдеу арқылы брикеттелген белсендірілген көмір алу үшін қоспаға карбоксиметилцеллюлоза қосылды. Брикетті карбонизациялау және белсендіру квариты шыныдан жасалған түтікте ұзындығы 300 мм және диаметрі 60 мм, қыздыру бөлімінің ұзындығы 200 мм болатын BR-12 NFT сериялы жоғары температуралы вакуумдық түтікті пеште жүргізілді. Пешке күріш қалдығы (қауызы мен сабаны), мұнай шламы және карбоксиметилцеллюлоза қосу арқылы алынған брикет орналастырылды. Карбонизация $500^{\circ} \mathrm{C}$ температурада, белсендіру $850^{\circ} \mathrm{C}$ температурада 2:1 қатынаста су буымен жүргізілді. Күріш қалдығы мен мұнай шламына карбоксиметилцеллюлоза байланыстырғышын қосу қатынастарының өнім қасиетіне әсері зерттелді. Қоспаны бірге өңдеудің оңтайлы қатынасы күріш қауызы:мұнай шламы: карбоксиметилцеллюлоза = 9:1:2 (массалары бойынша) қатынастары табылды. Алынған өнімнің йод бойынша адсорбциялық белсенділігі, су бойынша жалпы кеуектер көлемі, ылғалдың массалық үлесі, метилен көгі бойынша адсорбциялық белсенділігі және үйінділік тығыздығы тәрізді көрсеткіштер зерттелді. Жүргізілген зерттеулер нәтижесі бойынша белсендірілген көмірдің құрамындағы карбоксиметилцеллюлоза мөлшері артқан сайын оның собрциялық қасиетінің артатындығы байқалды. Күріш қауызынан алынған белсендірілген көмір жоғары сорбциялық қасиетке ие.Тәжірибелік зерттеулер нәтижесі бойынша 9:1:2 қатынастағы күріш қауызы мен мұнай шламы және карбоксиметилцеллюлозаны қосу арқылы алынған белсендірілеен көмір БАУ-А маркасына сәйкес келеді.

ТҮЙІн СөзДЕР: белсендірілген көмір, күріш қауызы, күріш сабаны, мұнай шламы, карбоксиметилцеллюлоза, карбонизация.

\section{ПОЛУЧЕНИЕ ГРАНУЛИРОВАННОГО УГОЛЬНОГО АДСОРБЕНТА СОВМЕСТНОЙ ПЕРЕРАБОТКОЙ РИСОВОЙ СОЛОМЫ И НЕФТЕШЛАМА}

Н.О. АППАЗОВ ${ }^{1,2}$, кандидат химических наук, профессор, и. о. председателя правления Казахского научно-исследовательского института рисоводства им. Ибрая Жахаева, https://orcid.org/0000-0001-8765-3386;

Б.М. ДИЯРОВА ${ }^{3 *}$, PhD-докторант по специальности «Химия», https://orcid.org/0000-0002-1086-369X; Б.М. БАЗАРБАЕВ ${ }^{1}$, инженер лаборатории инженерного профииля «Физико-химические методы анализа», http://orcid.org/0000-0003-1574-8145;

Т. АСЫЛБЕККЫЗЫ ${ }^{1}$, магистрант по специальности «Химическая технология неорганических веществ», orcid.org/0000-0001-5337-2164;

С.А. КАНЖАР ${ }^{1}$, студент по специальности «Химическая технология органических веществ», https://orcid.org/0000-0003-4553-3049

1'КЫЗЫЛОРДИНСКИЙ ГОСУДАРСТВЕННЫЙ УНИВЕРСИТЕТ ИМ. КОРКЫТ АТА, Республика Казахстан, 120014, г. Кызылорда, ул. Айтеке би, 29А

ГКАЗАХСКИЙ НАУЧНО-ИССЛЕДОВАТЕЛЬСКИЙ ИНСТИТУТ РИСОВОДСТВА ИМ. ИБРАЯЖАХАЕВА, Республика Казахстан, 120014, г. Кызылорда, проспект Абая 25Б

ЗКАЗАХСКИЙ НАЦИОНАЛЬНЫЙ ЖЕНСКИЙ ПЕДАГОГИЧЕСКИЙ УНИВЕРСИТЕТ,

Республика Казахстан, 050000, г. Алматы, ул. Айтеке би, 99 
В данной статье изучено влияние карбоксиметилцеллюлоза как связующего вещества, для получения брикетированного активированного угля путем совместной переработки отходов риса (шелухи и соломы) и нефтешлама. Карбонизацию и активацию брикета проводили в высокотемпературной вакуумной трубчатой печи серии BR-12 NFT длиной 200 мм, в нагревательной стеклянной трубке из кварца размером 300 мм и диаметром 60 мм. В печь помещали отход риса (шелуху или солому) в виде брикетированного с добавлением карбоксиметилцеллюлоза и нефтешлама. Карбонизацию проводили при температуре $500^{\circ} \mathrm{C}$, активацию - водяным паром при температуре $850^{\circ} \mathrm{C}$ в соотношении 2:1. Исследовано влияние соотношений карбоксиметилцеллюлозного связующего, отхода риса и нефттешлама на свойства активированного угля. Оптимальным соотношением совместной переработки смеси является рисовая шелуха: нефтешлам: карбоксиметилцеллюлоза 9:1:2 (по массе). Исследования проводились по следующим показателям: адсорбционная активность по йоду, общий объем пор по воде, массовая доля влаги, адсорбционная активность по метиленовому голубому и насыпная плотность. По результатам проведенных исследований было отмечено, что по мере увеличения содержания карбоксиметилцеллюлоза в активированном угле повышаются его сорбционные свойства. Активированный уголь, полученный на основе рисовой шелухи, обладает высокими сорбционными свойствами. По результатам экспериментальных исследований установлено, что активированный уголь, полученный из рисовой шелухи, нефртешлама и карбоксиметилцеллюлоза, в соотношениях 9:1:2 соответствует марке БАУ-А.

КЛЮЧЕВЫЕ СЛОВА: активированный уголь, рисовая шелуха, рисовая солома, нефртешлам, карбоксиметилцеллюлоза, карбонизация.

\section{OBTAINING A GRANULAR COAL ADSORBENT BY JOINT PROCESSING OF RICE STRAW AND OIL SLUDGE}

N.O. APPAZOV ${ }^{1,2}$, candidate of chemical sciences (PhD), professor, Director of the Kazakh Scientific Research Institute of Rice Cultivation named after Ibraya Zhakhaeva, https://orcid.org/0000-0001-8765-3386;

B.M. DIYAROVA3*, PhD student in Chemistry, https://orcid.org/0000-0002-1086-369X; B.M. BAZARBAYEV ${ }^{1}$, engineer of laboratory of engineering profile "Physical and chemical methods of analysis", http://orcid.org/0000-0003-1574-8145;

T. ASYLBEKKYZY", master's student in the specialty "Chemical technology of inorganic substances", https://orcid.org/0000-0001-5337-2164;

S.A. KANZHAR ${ }^{1}$, student majoring in Chemical Technology of Organic Substances, https://orcid.org/0000-0003-4553-3049

${ }^{1}$ KORKYT ATA KYZYLORDA STATE UNIVERSITY, Republic of Kazakhstan, 120014, Kyzylorda, 29A Aiteke bie str.

2I. ZHAKHAEV KAZAKH SCIENTIFIC RESEARCH INSTITUTE OF RICE GROWING, Republic of Kazakhstan, 120014, Kyzylorda, 25B Abay avenue

${ }^{3}$ KAZAKH STATE WOMEN'S TEACHER TRAINING UNIVERSITY, Republic of Kazakhstan, 050000, Almaty, Ayteke bi, 99

This article studies the effect of carboxymethyl cellulose as a binder for producing briquetted activated carbon by joint processing of rice waste (husk and straw) and oil sludge. The carbonization and activation of the briquette was carried out in a high-temperature vacuum tube furnace of the $B R-12$ NFT series with a length of $200 \mathrm{~mm}$, in a quartz heating glass tube $300 \mathrm{~mm}$ in size and $60 \mathrm{~mm}$ in diameter. Rice waste (husk or straw) in the form of briquetted rice with the addition of lignosulfonate and oil sludge was placed in the oven. Carbonization was carried out at a temperature of $500^{\circ} \mathrm{C}$, activation - with water vapor at a temperature of $850^{\circ} \mathrm{C}$ in a 2: 1 ratio. The influence of the ratios of carboxymethyl cellulose binder, rice waste and oil sludge on the properties of activated carbon has been studied. The optimal ratio of joint processing of the mixture is rice husk: oil sludge: carboxymethyl cellulose 9: 1: 2 (by weight). The studies were carried out according to the following 
indicators: adsorption activity for iodine, total pore volume for water, mass fraction of moisture, adsorption activity for methylene blue and bulk density. According to the results of the studies, it was noted that as the content of carboxymethyl cellulose in activated carbon increases, its sorption properties increase. Activated carbon based on rice husk has high sorption properties. According to the results of experimental studies, it was found that activated carbon obtained from rice husks, oil sludge and carboxymethyl cellulose in a ratio of 9: 1: 2 corresponds to the brand BAU-A.

KEY WORDS: activated carbon, rice husk, rice straw, oil sludge, carboxymethyl cellulose, carbonation.

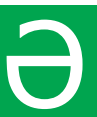

лемде белсендірілген көмірге деген қажеттілік жыл сайын өсу қарқыны артуда. Белсендірген көмір медицинада [1], энергияны сақтауда [2], ағынды суларды тазартуда [3,4], түтін газын тазартуда [5,6] оның жоғары жылу тұрақтылығы, үлкен адсорбция ауданы, жоғары көміртегі мазмұны және төмен химиялық реактивтілік қасиеттері негізінде [7,8] кеңінен қолдануға мүмкіндік береді. Белсендірілген көмірдің адсорбциялық тиімділігі алынатын бетінің ауданына әсер ететін шикізат пен оны дайындау әдістеріне байланысты.

Қазіргі таңда кеуекті көміртекті материал түтікті пешті немесе микротолқынды пешті қолдана отырып, екі сатылы термиялық өңдеу (карбонизация, содан кейін белсендіру) арқылы алынады. Бірінші кезең инертті атмосферада қыздыру және пиролиз арқылы шикізатты карбонизациялауды қажет етеді. Шикізат карбонизация кезінде дегидратацияланады (яғни су құрамын алып тастау) және деволатилденеді (яғни ұшпа заттарды алып тастау) және биочарға айналады [9]. Содан соң биочар физикалық (мысалы, бу және көмірқышқыл газы) немесе химиялық (мысалы, бу және көмірқышқыл газы, $\mathrm{KOH})$ ) қосымшаларды қосу негізінде кеуектілікті кеңейту арқылы сорбциялық қасиетін арттырады [10]. Сонымен қатар қазіргі таңда сорбциялық қасиетін арттырудың тағы бір жолы байланыстырғыштар болып табылады. Белсендірілген көмір алуда байланыстырғыштарды қосу оның сорбциялық қасиетін арттырады және брикеттеуге мүмкіндік береді.

"Брикеттеу" термині белгілі бір мөлшерде және пішінде, сондай-ақ жаңа құрылымдық - механикалық қасиеттері бар дисперсті қатты және сұйық фазалардан қатты дене құруды білдіреді [11]. Байланыстырғышпен байланысқан бөлшектерден алынған кез-келген материал - бұл беріктік үш негізгі факторға байланысты болатын жүйе: жүйені құрайтын денелердің адгезиясы, аутогезиясы және бірігуі.

Белсендірілген көмірмен адсорбциялық тазарту органикалық заттарды, хлорды, ауыр металдарды, сұйық қалдықтарды азайтудың тиімді құралы ретінде танылған [12]. Белсендірілген көмір алуда тас көмір [13-15], ағаш қалдықтары [16-18], кокос қабығы [19-21], шымтезек [22-24], петролеум [25-27] және полимерлер [28, 29] сияқты танымал шикізат көздері қолданылады.

Белсендірілген көмірді брекиттеудің көптеген тәсілдері белгілі, ағаш қалдықтарынан алынған белсендірілген көмірді қысыммен қыздырып біріктіріп, ұсақтап, карбонизациялап және белсендірген, соңғы өнімнің шығымын, оның беріктігі мен белсенділігін арттыру үшін біріктіру 200-230 С температурада және 1500-2000 кг қысымда 0,5-тен 1 минутқа дейін ұстаған. Ал келесі белсендірілген көмір алуда ұсақталған қалдықтарды алдымен 700-800 C температурада карбонизациялаған, содан соң оларды ұнтақталған күйге келтірген және байланыстырғыш ретінде мұнай 
пегі және сульфит - спирт барды қолданылған, алынған белсендірілген көмір кептіріліп, инертті ортада $600-800^{\circ} \mathrm{C}$ температурада пиролизденген және $650-800^{\circ} \mathrm{C}$ температурада 30-120 минут ішінде белсендірілген [30]. Белсендірілген көмірді алудың тағы бір әдісі, ол ұсақталған көмір шикізаты мен шайырлы байланыстырушыны араластырып, композицияны түйіршіктеген, түйіршіктерді салқындатып, оларды 450-650 ${ }^{\circ} \mathrm{C}$ - та карбонизациялаған және 850-950 $\mathrm{C}$ - та бу-газды ортада белсендірген, араластыру кезінде көмір - шайыр құрамына неонол 0,8-3,5 мас мөлшерінде қосылған [31].

Алдыңғы зерттеулерімізде күріш сабаны мен мұнай шламын со-термолиздеу және күріш қауызы мен мұнай шламын со-термолиздеу арқылы белсендірілген көмір алынды [32-33]. Ал бұл жолғы зерттеу жұмысымызда күріш қалдығы (қауызы және сабаны) мен мұнай шламынан белсендірілген көмір алуда байланыстырушы ретінде карбоксиметилцеллюлозаның әсері зерттелді. Әдеби шолуларда байланыстырушы ретінде карбосиметилцеллюза туралы мәліметтер аз, яғни бұл бағытта әлі де зерттеулер қажет.

\section{ТӘЖІРИБЕЛІК БӨЛІМ}

Күріш қалдығы мен мұнай шламына байланыстырушы карбоксиметилцеллюзаны қосу арқылы брикеттелді. Брикетті түтікті пеште $500^{\circ} \mathrm{C}$ температурада карбонизациялайды, ал $850^{\circ} \mathrm{C}$ температурада су буымен белсендіреді.

Алынған белсендірілген көмірдің йод бойынша адсорбциялық белсенділігі, су бойынша жалпы кеуектер көлемі, ылғалдың массалық үлесі, үйінділік тығыздығы, метилен көгі бойынша адсорбциялық белсенділігі анықталды.

Йод бойынша адсорбциялық белсенділікті анықтау үшін белсендірілген көмірдің белгілі бір бөлігіне калий йодидіндегі 0,1 моль/дм³ концентрациядағы йод ерітіндісі қосылып, араластырғыш қондырғыда қарқындылығы 100-125 тербелісте 15 минут бойы шайқалды. Одан кейін ерітінді тұнғанша күтіп, титрлеу үшін пипеткамен қажетті көлемді алады да индикатор ретінде крахмалды пайдаланып, көк түс жойылғанша 0,1 моль/дм³ натрий тиосульфаты ерітіндісімен титрлейді [34].

Су бойынша кеуектердің жинақтық көлемін анықтау үшін 0,5-104 нм аралығындағы кеуектерді 15 минут қыздыра отырып суда қайнатып, 8 кПа қысымда сорғылау арқылы судың артық мөлшерін бөліп, таразыда өлшеу арқылы анықтайды. Белсендірілген көмірдің үйінділік тығыздығын анықтау белгілі бір көлемдегі белсендірілген көмірді нормалап нығыздап, массасын өлшеу арқылы іске асырылды [35-36].

\section{НӘТИЖЕЛЕР ЖӘНЕ ТАЛКЫЛАУ}

Күріш қалдығы мен (қауызы және сабан) мұнай шламына карбоксиметилцеллюзаны қосу арқылы брекиттелген қоспа құбырлы пешке салынды. Герметикалық түрде жабылып, түтік цилиндрден жеткізілетін азот газымен толтырылды, карбонизация процесі минутына $10^{\circ} \mathrm{C}$ - тан $500^{\circ} \mathrm{C}$ - қа дейін көтеріліп, осы температурада 100 минут ұсталды, ал белсендіру $850^{\circ} \mathrm{C}$ температурада карбонизат және су буынының 2:1 қатынасында жүргізілді. Карбоксиметилцеллюза қатынасының белсендірілген көмірдің шығымы мен физика-химиялық қасиетіне әсері зерттелді. (Kecme 1)

Кестедегі мәліметтерге сүйенетін болсақ карбоксиметилцеллюлозаның үлесі артқан сайын йод бойынша адсорбциялық қасиеті, су бойынша жалпы кеуектер 
Кесте 1 - Күріш сабаны мен қауызын мұнай шламымен бірге өңдеуде байланыстырғыш ретінде карбоксиметилцеллюлозаны пайдалану арқылы алынған белсендірілген көмірдің қасиеттері

\begin{tabular}{|c|c|c|c|c|c|c|c|c|}
\hline \multirow{3}{*}{$\begin{array}{c}\text { Көрсеткіш атауы } \\
\text { Қатынас }\end{array}$} & \multicolumn{8}{|c|}{ Эксперименттік зерттеулердің нәтижесі } \\
\hline & $\begin{array}{c}\text { Күріш сабаны: } \\
\text { Карбоксиметил- } \\
\text { целлюлоза }\end{array}$ & \multicolumn{3}{|c|}{$\begin{array}{c}\text { Күріш сабаны: } \\
\text { Мұнай шламы: } \\
\text { Карбоксиметил- } \\
\text { целлюлоза }\end{array}$} & $\begin{array}{c}\text { Күріш қауызы: } \\
\text { Карбоксиметил- } \\
\text { целлюлоза }\end{array}$ & \multicolumn{3}{|c|}{$\begin{array}{l}\text { Күріш қауызы: } \\
\text { Мұнай шламы: } \\
\text { Карбоксиметил- } \\
\text { целлюлоза }\end{array}$} \\
\hline & 10:1 & 9:1:1,1 & $9: 1: 1,25$ & $9: 1: 2$ & 10:1 & $9: 1: 1,1$ & $9: 1: 1,25$ & 9:1:2 \\
\hline $\begin{array}{c}\text { Карбонизация } \\
\text { температурасы, }{ }^{\circ} \mathrm{C}\end{array}$ & \multicolumn{8}{|c|}{500} \\
\hline $\begin{array}{c}\text { Карбонизат, } \\
\text { шығымы мас \% }\end{array}$ & 76,5 & 84,25 & 64,44 & 77,66 & 71,19 & 70,5 & 87,18 & 72,63 \\
\hline $\begin{array}{c}\text { Белсендіру } \\
\text { температурасы, }{ }^{\circ} \mathrm{C}\end{array}$ & \multicolumn{8}{|c|}{850} \\
\hline $\begin{array}{c}\text { Су:карбонизат } \\
\text { қатынас }\end{array}$ & \multicolumn{8}{|c|}{ 2:1 } \\
\hline $\begin{array}{c}\text { Белсендірілген } \\
\text { көмір шығымы, } \\
\text { мас. \%. }\end{array}$ & $22,59 \%$ & $29,6 \%$ & $36,71 \%$ & $26,65 \%$ & $35 \%$ & $35,7 \%$ & $31,74 \%$ & $31,67 \%$ \\
\hline $\begin{array}{l}\text { Йод бойынша } \\
\text { адсорбциялық } \\
\text { белсенділік, \% }\end{array}$ & 33,08 & 33,12 & 39,31 & 49,53 & 50,65 & 53,23 & 68,58 & 69,78 \\
\hline $\begin{array}{c}\text { Су бойынша жалпы } \\
\text { кеуектер көлемі, } \\
\text { см³ } / г^{3}\end{array}$ & 0,672 & 0,712 & 0,762 & 0,852 & 0,741 & 0,764 & 0,772 & 0,789 \\
\hline $\begin{array}{c}\text { Ылғалдың } \\
\text { массалық үлесі, \% }\end{array}$ & 2,30 & 2,71 & 2,73 & 2,78 & 0,9 & 1,37 & 1,66 & 1,79 \\
\hline $\begin{array}{c}\text { Үйінділік } \\
\text { тығыздық, г/дм³ }\end{array}$ & 219,23 & 223,05 & 229,75 & 257,61 & 413,35 & 428,45 & 456,10 & 476,02 \\
\hline $\begin{array}{c}\text { Метилен көгі } \\
\text { бойынша } \\
\text { адсорбциялық } \\
\text { белсенділік мг/г }\end{array}$ & 386,37 & 380,20 & 385,25 & 341,35 & 351,20 & 356,00 & 360,77 & 371,17 \\
\hline
\end{tabular}

көлемі, үйінділік тығыздығы, метилен көгі бойынша адсорбциялық белсенділігі жоғарылаған. Күріш сабанына қарағанда күріш қауызынан алынған белсендірілген көмірдің физика-химиялық қасиеттерінің мәндері жоғары. 


\section{қОРЫТЫНДЫ}

Корыта келгенде күріш қауызы:мұнай иламы:лигносульфонат = 9:1:2 қатынаста оңтайлы жсаддайы болып табылды. Алындан белсендірілген көмірдің йод бойынша адсорбциялық белсенділіхі 69,78\%-ды көрсетті. Зерттеу нәтижелері бойынша 9:1:2 қатынаставы күріш қауызымен мұнай иламына байланыстырzыш карбоксиметилцеллюлозаны қосу арқылы алындан белсендірілген көмір БАУ-А маркасына сәйкес келеді.

Жұмыс АР05134356 гранттық қаржыландыру есебінен ҚР БҒМ және Ғылым комитетінің құолдауымен жүзеге асырылды 8.

\section{ӘДЕБИЕТ}

1 Ramanujan R.V., Purushotham S., Chia M.H. Processing and characterization of activated carbon coated magnetic particles for biomedical applications. Mater. Sci. Eng., 2007, vol. 27. no. 4. pp. 659-664. DOI: 10.1016/j.msec.2006.06.007-2007-27-4-659-664.

2 Liu Caihong; Koyyalamudi Bhaskar Babu, Li Ling, Emani Satya; Wang Chuanlong; Shaw Leon. Improved capacitive energy storage via surface functionalization of activated carbon as cathodes for lithium ion capacitors. Carbon, 2016, vol. 109. pp.163-172. DOI: 10.1016/j. carbon.2016.07.071-2016-109-163-172 - 2016-109-163-172.

3 Karelid, Victor, Larsson Gen, Bjorlenius Berndt Pilot-scale removal of pharmaceuticals in municipal wastewater: Comparison of granular and powdered activated carbon treatment at three wastewater treatment plants. J. Environ. Manag., 2017, vol.193. pp. 491-502. DOI: 10.1016/j.jenvman.2017.02.042-2017-193-491502 - 2017-193-491-502.

4 Liew Rock Keey,Chai Carmil; Yek Peter Nai Yuh ; Phang Xue Yee; Chong Min Yee; Nam Wai Lun; Su Man Huan, Lam, Wei Haur, Ma Nyuk Ling, Lam Su Shiung. Innovative production of highly porous carbon for industrial effluent remediation via microwave vacuum pyrolysis plus sodium-potassium hydroxide mixture activation. J. Clean. Prod., 2019. vol. 208. pp.1436-1445. DOI: 10.1016/j.jclepro.2018.10.214 - 2019-208-1436-1445.

5 Feng T., Huo M., Zhao X., Wang T., Xia X., Ma C. Reduction of SO2 to elemental sulfur with $\mathrm{H} 2$ and mixed $\mathrm{H} 2 / \mathrm{CO}$ gas in an activated carbon bed. Chem. Eng. Res. Des., 2017, vol.121, pp.191-199. DOI: 10.1016/j.cherd.2017.03.014 - 2017-121-191-199.

6 Li Sujing, Wang Xiaoxiang; Tan Shan, Shi Yun, Li Wei.CrO3 supported on sargassumbased activated carbon as low temperature catalysts for the selective catalytic reduction of NO with NH3. Fuel, 2017b, vol. 191. pp. 511-517. DOI: 10.1016/j.fuel.2016.11.095-2017b191-511-517

7 Lam S.S., Liew R.K., Wong Y.M., Yek P.N.Y., Ma N.L., Lee C.L., Chase H.A., Microwaveassisted pyrolysis with chemical activation, an innovative method to convert orange peel into activated carbon with improved properties as dye adsorbent. J. Clean. Prod., 2017b, vol.162. pp.1376-1387. doi.org/10.1016/j.jclepro.2017.06.131 - 2017b162-1376-1387.

8 Liew Rock Keey, Chong Min Yee, Osazuwa Osarieme Uyi, Nam Wai Lun, Phang Xue Yee, Su Man Huan, Cheng Chin Kui, Chong Cheng Tung, Lam Su Shiung. Production of activated carbon as catalyst support by microwave pyrolysis of palm kernel shell: a comparative study of chemical versus physical activation. Res. Chem. Intermediat., 2018a, vol. 44. pp. 3849-3865. DOI: 10.1007/s11164-018-3388-y- 2018a-44-3849-3865.

9 Lam S.S., Liew R.K., Cheng C.K., Rasit N., Ooi C.K., Ma N.L., Ng J.-H., Lam W.H., Chong C.T. Chase H.A. Pyrolysis production of fruit peel biochar for potential use in treatment of 
palm oill mill effluent. J. Environ. Managen. 2018a, vol. 213. pp.400-408. DOI: 10.1016/j. jenvman.2018.02.092 - 2018a-213-400-408.

10 Liew R.K., Azwar E., Yek P.N.Y., Lim X.Y., Cheng C.K., Ng J.-H., Jusoh A., Lam W.H. Ibrahim M.D., Ma N.L. Microwave pyrolysis with $\mathrm{KOH} / \mathrm{NaOH}$ mixture activation: a new approach to produce micro-mesoporous activated carbon for textile dye adsorption. Bioresour. Technol., 2018b, vol. 266. pp.1-10. DOI: 10.1016/j.biortech.2018.06.051 2018b-266-1-10. 11 Нордштрем Э.К., Ойстрах Э.Н. Брикетирование угля и древесно-угольной мелочи. Гидролиз и лесохим. пром-сть. - 1955. - № 6. - С. 30. [Nordshtrem E.K., Oystrakh E.N. Briketirovaniye uglya i drevesno-ugol'noy melochi. Gidroliz i lesokhim. prom-st'. - 1955. - № 6. - C. 30.]

12 Wen Q.B., Li C., Cai Z., Zhang W., GAO H., Chen L., Zeng G., Shu X., Zhao Y. Study on activated carbon derived from sewage sludge for adsorption of gaseous formaldehyde. Bioresource Technology., 2011, vol. 102. no. 2. pp. $942-947$. DOI: 10.1016/j. biortech.2010.09.042. - 2011-102-2-942-947 - 2011-102-2-942-947.

13 Qada E.N.El., Allen S.J., Walker G.M. Adsorption of Methylene Blue onto activated carbon produced from steam activated bituminous coal: A study of equilibrium adsorption isotherm. Chemical Engineering Journal, 2006, vol. 124. vol. 1-3. pp. 103 - 110. DOI: 10.1016/j. cej.2006.08.015 - 2006-124-1-3-103-110.

14 Zhang C., Long D., Xing B., Qiao W., Zhang R., Zhan L., Liang X., Ling L., Zhang, C. The superior electrochemical performance of oxygen-rich activated carbons prepared from bituminous coal. Electrochemistry Communications, 2008, vol. 10. no. 11. pp. 1809 1811. DOI: 10.1016/j.elecom.2008.09.019 - 2008-10-11-1809-1811.

15 Jibril B., Al Maamari R.S., Hegde G., Houache O. Effects of feedstock pre-drying on carbonization of $\mathrm{KOH}$ mixed bituminous coal in preparation of activated carbon. Journal of Analytical and Applied Pyrolysis, 2007, vol. 80. no. 2. pp. 277-282. DOI: 10.1016/j. jaap.2007.03.003 - 2007-80-2-277-282.

16 Sahu J.N., Acharya J., Meikap B.C. Optimization of production conditions for activated carbons from Tamarind wood by zinc chloride using response surface methodology. Bioresource Technology, 2010, vol. 101. no. 6. pp. 1974 - 1982. DOI: 10.1016/j.biorte ch.2009.10.031-2010-101-6-1974-1982

17 Yorgun S., Vural N., Demiral H. Preparation of high-surface area activated carbons from Paulownia wood by $\mathrm{ZnCl} 2$ activation. Microporous and Mesoporous Materials, 2009, vol. 122. no. 1-3. pp. 189 - 194. DOI: 10.1016/j.micromeso.2009.02.03-2009-122-1-3-189-194.

18 Acharya, J ., Sahu J.N., Sahoo B. K., Mohanty C.R., Meikap B.C. Removal of chromium(VI) from wastewater by activated carbon developed from Tamarind wood activated with zinc chloride. Chemical Engineering Journal, 2009, vol.150. no. 1. pp. 25 - 39. DOI: 10.1016/j. cej.2008.11.035-2009-150-1-25-39.

19 Yang, K.B., Peng J., Srinivasakannan C., Zhang L., Xia H., Duan X. Preparation of high surface area activated carbon from coconut shells using microwave heating. Bioresource Technology. 2010, Vol. 101. No. 15. pp 6163 - 6169. DOI: 10.1016/j.biorte ch.2010.03.0012010-101-15-6263-6169.

20 Afrane G., Achaw O.W. Effect of the concentration of inherent mineral elements on the adsorption capacity of coconut shell-based activated carbons. Bioresource Technology, 2008, vol. 99. no. 14. pp. 6678 - 6682. DOI: 10.1016/j.biorte ch.2007.11.071-2008-9914-6678-6682.

21 Guo,S., Peng J., Li W., Yang K., Zhang L., Zhang S., Xia H. Effects of CO2 activation on porous structures of coconut shell-based activated carbons. Applied Surface Science, 2009, vol. 255. no 20. pp. 8443 - 8449. DOI: 10.1016/j.apsu sc.2009.05.150-2009-25520-8443-8449. 
22 Donald J., Xua C., Hashimotob H., Byambajavb E., Ohtsuka Y. Novel carbon-based Ni/ Fe catalysts derived from peat for hot gas ammonia decomposition in an inert helium atmosphere. Applied Catalysis A: General, 2010, vol. 375. no. 1. pp. 124 - 133. DOI: 10.1016/j.apcata.2009.12.0302010-375-1-124-133.

23 Veksha A., Sasaoka E., Uddin Md.A. The influence of porosity and surface oxygen groups of peatbased activated carbons on benzene adsorption from dry and humid air. Carbon, 2009, vol. 47. no. 10. pp. 2371 - 2378. 178. doi.org/10.1016/j.carb on.2009.04.028-200947-10-2371-2378.

24 Veksha A., Sasaoka E., Uddin Md.A. The effects of temperature on the activation of peat char in the presence of high calcium content. Journal of Analytical and Applied Pyrolysis, 2008, vol. 83. No. 1. pp. 131 - 136. DOI: 10.1016/j.jaap.2008.07.001-2008-83-1-131-136.

25 Ganan-Gomez J., Macias-Garcia A., Diaz-Diez M.A., Gonzalez-Garcia C., Sabio-Rey E. Preparation and characterization of activated carbons from impregnation pitch by $\mathrm{ZnCl} 2$. Applied Surface Science, 2006, vol. 252. no.17. pp. 5976 - 5979. DOI: 10.1016/j.apsu sc.2005.11.011-2006-252-17-5976-5979.

26 Ma J., Tan J., Du X., Li R. Effects of preparation parameters on the textural features of a granular zeolite/activated carbon composite material synthesized from elutrilithe and pitch. Microporous and Mesoporous Materials, 2010, vol. 132. no. 3. pp. 458 - 463. DOI: 10.1016/j.micromeso.2010.03.027-2010-132-3-458-463.

27 Kumar, K.V., Castro M.M., Escandell M.M., Sabio M.M., Reinoso F.R. Neural network and principal component analysis for modeling of hydrogen adsorption isotherms on $\mathrm{KOH}$ activated pitch-based carbons containing different heteroatoms Chemical Engineering Journal, 2010, vol. 159. no. 1-3. pp. 272 - 279. DOI: 10.1016/j.cej.2010.01.059-2010159-1-3-272-279.

28 Seredych M., Deliyanni E.A., Bandosz T.J. Role of microporosity and surface chemistry in adsorption of 4, 6-dimethyldibenzothiophene on polymer-derived activated carbons. Fuel, 2010, vol. 89. no. 7. pp. 1499 - 1507. DOI: 10.1016/j.fuel.2009.09.032-2010-89-71499-1507.

29 Zhu Z., Li A., Yan L., Liu F., Zhang Q. Preparation and characterization of highly mesoporous spherical activated carbons from divinylbenzene-derived polymer by $\mathrm{ZnCl} 2$ activation . Journal of Colloid and Interface Science, 2007, vol. 316. no. 2. pp. 628 - 634 . DOI: 10.1016/j.jcis.2007.09.016-2007-316-2-628-634.

30 Патент РФ № 2006143313/15 на изобретение. Способ получения гранулированного активного угля / Передерий М.А., Маликов И.Н. и др.; дата опубл. 07.12.2006. [Patent RF № 2006143313/15, na izobreteniye. Sposob polucheniya granulirovannogo aktivnogo uglya / Perederiy M.A., Malikov I.N. i dr.; data opubl. 07.12.2006. Byull. №23. (In Russ.)].

31 Патент РФ № 98121153/12 на изобретение. Способ получения гранулированного активного угля / Клушин В.Н., Мухин В.М. и др.; дата опуб. 24.11.1998. [Patent RF № 98121153/12 na izobreteniye. Sposob polucheniya granulirovannogo aktivnogo uglya / Klushin V.N., Mukhin V.M. i dr.; data opub. 24.11.1998. Byull. №2. (In Russ.)].

32 Аппазов Н.О., Турманов Р.А., Жаппарбергенов Р.У., Диярова Б.М., Лыгина О.С., Шурагазиева А.Т., Акылбеков Н.И. Получение активированного угля со-термолизом рисовой шелухи и нефтешлама // Химический журнал Казахстана. - 2019. №4. - C. 77-83. [Appazov N.O., Turmanov R.A., Zhapparbergenov R.U., Diyarova B.M., Lygina O.S., Shuragazieva A.T., Akylbekov N.I. Poluchenie aktivirovannogo uglja so-termolizom risovoj sheluhi i nefteshlama // Himicheskij zhurnal Kazahstana. - 2019. №4. - S. 77-83.]. 
33 Аппазов, Н.О., Базарбаев Б.М., Диярова Б.М., Лыгина О.С., Шурагазиева А.Т., Акылбеков Н.И. Получение активированного угля со-термолизом рисовой соломы и нефтешлама // Химический журнал Казахстана. - 2019. - №4: - C. 46-51. [Appazov, N.O, B.M. Bazarbaev, B.M. Diyarova, O.S. Lygina, A.T. Shuragazieva, N.I. Akylbekov. Poluchenie aktivirovannogo uglja so-termolizom risovoj solomy i nefteshlama. Himicheskij zhurnal Kazahstana. - 2019. - №4: - S. 46-51.]

34 ГОСТ 6217. Уголь активный древесный дробленый. Технические условия. - М.: ИПК Издательство стандартов, 2003. [GOST 6217. Ugol' aktivnyy drevesnyy droblenyy. Tekhnicheskiye usloviya. - M.: IPK Izdatel'stvo standartov, 2003. ].

35 ГОСТ 17219. Угли активные. Метод определения суммарного объема пор по воде. М.: Издательство стандартов, 1988. [GOST 17219. Ugli aktivnyye. Metod opredeleniya summarnogo ob"yema por po vode. - M.: Izdatel'stvo standartov, 1988.].

36 ГОСТ 16190. Сорбенты. Метод определения насыпной плотности. - М.: Издательство стандартов, 1970. [GOST 16190. Sorbenty. Metod opredeleniya nasypnoy plotnosti. M.: Izdatel'stvo standartov, 1970. ]. 